\title{
Photosynthetic response to nitrogen source and different ratios of nitrogen and phosphorus in toxic cyanobacteria, Microcystis aeruginosa FACHB-905
}

\author{
Guotao PENG, Zhengqiu FAN, Xiangrong WANG, ${ }^{*}$ Chen CHEN \\ Department of Environmental Science and Engineering, Fudan University, No. 220 Handan Road, Yangpu District, Shanghai 200433, \\ China \\ *Corresponding author: xrxrwang@fudan.edu.cn
}

\begin{abstract}
The frequent outbreak of cyanobacterial blooms has become a worldwide phenomenon in freshwater ecosystems. Studies have elucidated the close relationship between harmful algal blooms and nutrient contents, including the loading of nitrogen and the ratios of nitrogen ( $N$ ) and phosphorus (P). In this study, the effect of inorganic (nitrate and ammonium) and organic (urea) nitrogen at varied N/P ratios on the Microcystis aeruginosa $F A C H B-905$ accumulation and photosynthesis was investigated. The optimal $\mathrm{NO}_{3} / \mathrm{P}$ in this study were $30 \sim 50$ indicated by the cell abundance $\left(4.1 \times 10^{6} / \mathrm{mL}\right)$, pigment concentration (chlorophyll a $3.1 \mathrm{mg} / \mathrm{L}$, phycocyanin $8.3 \mathrm{mg} / \mathrm{L}$ ), and chlorophyll fluorescence parameters ( $\mathrm{rETR}, \mathrm{E}_{\mathrm{k}}, \alpha, \varphi \mathrm{PSII}$ and $\mathrm{F}_{\mathrm{v}} / \mathrm{F}_{\mathrm{m}}$ values), while too high $N O_{3}-N(N / P=100: 1)$ would cause an intracellular nitrate inhibition, leading to a decrease of photosynthetic activity. In addition, low concentration of $\mathrm{NH}_{4}-\mathrm{N}(\mathrm{N} / \mathrm{P}=4: 1)$ would favor the M. aeruginosa growth and photosynthesis, and high $\mathrm{NH}_{4} / \mathrm{P}$ ratio $(>16)$ would rise the ammonium toxicity of algal cells and affect the $N$ assimilation. In urea treatments, M. aeruginosa responded similarly to the $\mathrm{NH}_{4}-\mathrm{N}$ treatments both in growth curves and pigment contents, and the favorable N/P ratio was between 16 30, suggested by the chlorophyll fluorescence parameters. The results demonstrated that the various chemical forms of N and N/P ratios have a significant impact on Microcystis abundance and photosynthesis. More work is needed to figure out the mechanism of nitrogen utilization by Microcystis and the photosynthetic response to nutrient stress at the molecular level.
\end{abstract}

Key words: Microcystis; nitrogen form; N/P ratio; photosynthesis; chlorophyll fluorescence parameters.

Received: February 2016. Accepted: May 2016.

\section{INTRODUCTION}

Harmful algal blooms (HABs) have been a major environmental concern in both marine and freshwater throughout the world (Wilhelm et al., 2014; Lehman et al., 2015). Among the organisms involved, Microcystis is perhaps the most notorious, since the hepatotoxins (especially microcystins) produced can decrease the richness of wild animals (White et al., 2005), poison human and domestic livestock (Peng et al., 2015). The environmental parameters particularly temperature, light, high $\mathrm{pH} /$ low $\mathrm{CO}_{2}$, nutrient availability and trace elements have been suggested to lead to cyanobacterial dominance (Barbiero et al., 1999; Aneesh et al., 2015).

Phosphorus is widely accepted as the main nutrient controlling the development of natural populations of cyanobacteria in many freshwater environments for decades (Schindler, 1977). However, the potential role of nitrogen concentrations and chemical forms in driving $\mathrm{Mi}$ crocystis bloom formation and biological community structure has gained widespread attention in recent years. It has been suggested that high $\mathrm{NO}_{3}-\mathrm{N}$ level promotes the advantage of Microcystis (Lehman et al., 2009). Opposite results were obtained by Moisander et al. (2009) who found that Microcystis abundance increased in response to all forms of $\mathrm{N}$, at no limiting conditions. In addition, Donald et al. (2011) explored that the $\mathrm{NH}_{4}-\mathrm{N}$ and urea favored non-heterocystous cyanobacteria, and microcystin production was increased by up to 13 -fold after $\mathrm{N}$ added. Belisle et al. (2016) also evaluated the urea distribution and the urease activity in Lake Erie and confirmed that organic nitrogen source was an important driver of cyanobacterial blooms and toxin production.

Among the major hypotheses that have been proposed to explain the cyanobacteria bloom, the prevalent may be that of the TN/TP ratio. Smith (1983) put forward that the low N/P ratios ( $<29$, by mass) favored dominance by bluegreen algae in lake phytoplankton, which promoted the research of N/P ratio on the HABs. Hyenstrand et al. (1998) concluded that a low N/P mass ratio (29) was one of the nine main factors influencing the success of cyanobacteria, while high N/P mass ratios (20-50) lead to a community dominated by green algae (Bulgakov and Levich, 1999) or diatoms (Mccarthy et al., 2009). Nevertheless, Nalewajko and Murphy (2001) found that the optimal growth rate of Microcystis aeruginosa isolated from the Lake Biwa occurred at the N/P mass ratio of 100:1 and declined at lower ratios ( $\mathrm{N}$ limitation) and high ratios (P limitation).

Pulse Amplitude Modulated (PAM) fluorometry has become one of the most common, non-invasive and rapid 
techniques to measure the variability of chlorophyll fluorescence to monitor the photosynthetic response of microalgae under different nutrient conditions (Wang et al., 2010). The following PAM parameters are generally used to measure the physiological state of the organism: rapid light curves (RLCs), relative photosynthetic electron transport $(r E T R)$, light saturation $\left(E_{k}\right)$, photosynthetic efficiency $(\alpha)$, actual photochemical efficiency of PSII $(\varphi P S I I)$ and maximum quantum photochemical efficiency of PSII $\left(F_{v} / F_{m}\right)$. Specifically, RLCs provided detailed information on the saturation characteristics of the electron transport chain as well as the overall photosynthetic performance exhibited by the microalgae (Ralph and Gademann, 2005). $r E T R$ is a measure of the rate of linear electron transport through PSII, while $E_{k}$ defines the onset of light saturation as obtained from the curves (Juneau et al., 2005). $\varphi P S I I$ and $F_{v} / F_{m}$ are used to estimate nutrient limitation, which have been found to decrease in nutrient stressed cultures (Schreiber et al., 2002; White et al., 2011).

Despite the clear importance of nitrogen in aquatic systems, the effects of various chemical forms of $\mathrm{N}$ and N/P ratios on Microcystis abundance are not consistent in previous studies, and few have evaluated the response of Microcystis photosynthetic activity. The goal of this study was to address this knowledge gap, studying the response of Microcystis to different forms of $\mathrm{N}$ and at different N/P ratios. In our experiments, Microcystis aeruginosa were cultivated in three different conditions, using chemical forms of nitrogen and different mass ratios of N/P medium. Cell numbers, key pigment concentration and chlorophyll fluorescence parameters $\left(r E T R, E_{k}, \alpha, \varphi P S I I\right.$ and $F_{v} / F_{m}$ ) were measured to figure out the microalgal cell growth and photosynthetic response to nutrient treatments, which aims to determine if different chemical forms of $\mathrm{N}$ and $\mathrm{N} / \mathrm{P}$ ratio influence the accumulation of Microcystis biomass and photosynthesis.

\section{METHODS}

\section{Strain and experimental design}

Microcystis aeruginosa (FACHB-905) was purchased from the Institute of Hydrobiology, Chinese Academy of Sciences (Wuhan, China), cultured with BG-11 medium (Rippka et al., 1979). Cultures in exponential phase were centrifuged at $6000 \mathrm{xg}$ for $10 \mathrm{~min}$, and the pelleted cells were washed three times with nitrogen-free $\mathrm{BG}_{11}$ medium. Subsequently, cultures were nitrogen starved for $72 \mathrm{~h}$ under the conditions of $25^{\circ} \mathrm{C}$, light intensity of $40 \mu \mathrm{mol}$ photons $\mathrm{m}^{-2} \mathrm{~s}^{-1}$, and a 12:12 LD cycle. After nitrogen starvation, the cells were re-inoculated into modified BG11 medium, with the initial cell density of $2.16 \times 10^{6} \mathrm{~mL}^{-1}$. Three chemical forms of nitrogen were chosen: nitrate $\left(\mathrm{NaNO}_{3}\right)$, ammonium $\left(\mathrm{NH}_{4} \mathrm{Cl}\right)$ and urea $\left(\left[\mathrm{NH}_{2}\right]_{2} \mathrm{CO}\right)$ at different mass ratios of N/P: 100:1, 50:1, 30:1, 16:1, 4:1.
The phosphorus concentration in each treatment was set as $1.0 \mathrm{mg} \mathrm{L}^{-1}$ (as $\mathrm{K}_{2} \mathrm{HPO}_{4}$ ).

\section{Measurement of cell abundance}

The cell abundance was determined daily by measuring the absorbance at $650 \mathrm{~nm}$ of each treatment. The relationship between the absorbance and the algal cell abundance was studied previously, with a gradient concentration of $M$. aeruginosa solutions cultured with standard $\mathrm{BG}_{11}$ medium. The number of single cells was counted using a haemocytometer (QIUJING, Shanghai, cell depth: $0.100 \mathrm{~mm} \pm 2 \%$ $(1 / 10 \mathrm{~mm})$, ruling pattern: improved Neubauer, $1 / 400$ square $\mathrm{mm}$ ) while the absorbance at $650 \mathrm{~nm}$ was measured with a spectrofluorophotometer (UV-2100, UNICO, Shanghai, China). The relationship between the absorbance and the cell density fits the linear regression equation:

$$
y=5.0856 x-0.2132
$$

Where $x$ is the absorbance at $650 \mathrm{~nm}, y$ is the algal cell density $\left(10^{6} \mathrm{~mL}^{-1}\right), \mathrm{R}^{2}=0.9717$.

\section{Measurement of pigment concentration}

To determine the pigment concentration, $50 \mathrm{~mL}$ samples were filtered onto Whatman GF/C filters $(0.22 \mu \mathrm{m})$ every three days. Chlorophyll- $a$ was extracted using $90 \%$ acetone for $24 \mathrm{~h}$ in the dark at $4{ }^{\circ} \mathrm{C}$ (Parsons et al., 1984). For phycocyanin (PC), the filters were extracted using $0.05 \mathrm{M}$ (pH6.8) phosphate buffer solution (PBS) and then processed by repetitive freezing in liquid nitrogen and thawing at $4^{\circ} \mathrm{C}$ for three times (Padgett and Krogmann, 1987). The absorbance at $630,645,663$ and $750 \mathrm{~nm}$ were measured to calculate the concentration of chlorophyll- $a$ according to the formula (Parsons et al., 1984):

$$
\begin{aligned}
C\left(m g L^{-1}\right)= & 10^{-3}\left[11.64\left(0 D_{663}-0 D_{750}\right)-2.16\left(0 D_{645}-0 D_{750}\right)\right. \\
& \left.+0.10\left(0 D_{630}-0 D_{750}\right)\right] V_{1} V^{-1} \delta^{-1}
\end{aligned}
$$

where:

$V$ is the volume of the sampling $(50 \mathrm{~mL})$;

$V_{I}$ is the constant volume of the extracted cultures each time $(10 \mathrm{~mL})$;

$\delta$ is the range of the cuvette $(1 \mathrm{~cm})$.

As to the phycocyanin, the concentration was calculated from the following equation (Padgett and Krogmann, 1987):

$$
C\left(m g L^{-1}\right)=10^{3}\left(O D_{620}-0.70 D_{650}\right) 7.38^{-1}
$$

\section{Photochemical activity assay}

Differences between the $\mathrm{N}$ forms and N/P ratio treatments were investigated with a WATER-PAM Chlorophyll Fluorometer (Walz, Effeltrich, Germany). The 
Rapid Light Curves (RLC) were measured by increasing the actinic irradiance stepwise from 56 to $915 \mu \mathrm{mol}$ photons $\mathrm{m}^{-2} \mathrm{~s}^{-1}$ with a saturation pulse of blue light (about $1800 \mu \mathrm{mol}$ photons $\mathrm{m}^{-2} \mathrm{~s}^{-1}, 600 \mathrm{~ms}$ ) every 20 s. rETR was estimated from the actual PSII photochemical yield measured at different photosynthetic photon flux densities (PPFDs) (Schreiber et al., 2000):

$$
\text { rETR }=0.42\left(F_{m}{ }^{\prime}-F_{t}\right) F_{m}{ }^{-1} \text { PPFD }
$$

where: $F_{m}$ ' and $F_{t}$ denote the maximum and steady state fluorescence in light, respectively.

The maximal rate of $r E T R\left(r E T R_{\max }\right)$ and photosynthetic efficiency $(\alpha)$ were determined by fitting the rapid light response curve to an exponential function modified from Platt (1980):

$$
r E T R=r E T R_{\max }\left(1-e^{-\alpha I r E T R_{\max }}{ }^{-1}\right)
$$

where $I$ represents the irradiance.

The saturation values $\left(E_{k}\right)$ are determined from the interception point of $\alpha$ value with the maximum photosynthetic rate, which follows the equation (Platt et al., 1980):

$$
E_{k}=r E T R_{\text {max }} \alpha^{-1}
$$

$P$ PSII was calculated by the formula (Genty et al., 1989):

$$
\varphi \mathrm{PSII}=\left(F_{m}{ }^{-}-F_{S}\right) F_{m}{ }^{-1}
$$

Where $F_{s}$ is linked to PSII reaction center closure.

$F_{v} / F_{m}$ was calculated by the following formula (Ting and Owens, 1992):

$$
F_{v} / F_{m}=\left(F_{m}-F_{o}\right) F_{m}^{-1}
$$

Where $F_{o}$ is the fluorescence of dark-adapted cells stimulated by a weak probe light immediately following 15 min of darkness; $F_{m}$ is the maximum fluorescence signal following the closure of all reaction centers by a 600 ms pulse of saturating irradiance.

\section{Statistical analysis}

All experiments were performed on three replicates and the data were reported as the average \pm standard deviation. One-way analysis of variance (ANOVA) was carried out to test the differences in data $(P<0.05)$ between the varied treatments using the Origin 8.0 (OriginLab). Tukey's post-hoc tests were used to locate the differences in the significant results.

\section{RESULTS}

\section{Cell abundance}

Microcystis cell abundance was stable for six days in all treatments, and the exponential growth phase started from then on. The growth curves of the nitrate cultures were similar at the N/P ratios of 100:1, 50:1, 30:1 and 16:1, with no significant differences found in the cell density (oneway ANOVA). The maximum cell abundance was about $4.1 \times 10^{6} \mathrm{~mL}^{-1}$ obtained at day 13 while it decreased markedly at the N/P ratio of 4:1 from day 12 (Fig. 1a). As for the treatments with $\mathrm{NH}_{4} \mathrm{Cl}$ medium, the N/P ratio of 16:1 and 4:1 were superior for the algal growth, which increased rapidly from day 6 , and the latter ones occupied the highest cell abundance $(P<0.05)$, but nearly fell to 0 at the end of the culture period. The peak number of cell density reached about $3.7 \times 10^{6} \mathrm{~mL}^{-1}$ at the $\mathrm{N} / \mathrm{P}$ ratio of $16: 1$ and $4: 1$ at day 12 (no significant difference, Fig. 1b) while the other three groups turned to decline since day 9. For the cultures with organic $\mathrm{N}$ medium (Fig. 1c), it is interesting to note that the more $\mathrm{N}$-concentrated cultures have the lower cell abundance. The cultures at the N/P ratio of 100:1 and 50:1 declined since day 9 . The N/P ratio of $4: 1$ was beneficial for the algal growth for the first 12 days while the decline phase started from then on. The maximum cell density was about $3.8 \times 10^{6} \mathrm{~mL}^{-1}$, appeared at day 14 at the N/P ratios of 16:1 $(P<0.05)$. Overall, the maximum cell abundance was significantly high at the nitrate treatments $(P<0.05)$, while no significant difference was found between the ammonium and urea treatments (one-way ANOVA).

\section{Pigment concentration}

The Chlorophyll- $a(\mathrm{Chl} a)$ and phycocyanin $(\mathrm{PC})$ concentrations in the cultures with different medium have been displayed in Fig. 2. For the M. aeruginosa cultured with the $\mathrm{NaNO}_{3}$ medium at different N/P ratios, the Chl $a$ concentration and PC concentration were in the trend of rising in the first 12 days and decreased slightly then, except the N/P ratio of 4:1, which exhibited the lowest values. The highest $\mathrm{Chl} a$ concentration was obtained at the N/P ratio of 100:1 (3.1 $\left.\mathrm{mg} \mathrm{L}^{-1}, P<0.05\right)$, with the corresponding PC content of $7.5 \mathrm{mg} \mathrm{L}^{-1}$. The peak content of PC $\left(8.3 \mathrm{mg} \mathrm{L}^{-1}\right)$ appeared at day 12 at the N/P ratio of 50:1 $(P<0.05$, Fig. 2a).

Maximum Chl $a$ and PC pigment was 2.1 and $8.2 \mathrm{mg}$ $\mathrm{L}^{-1}$, respectively, in the ammonium treatment at the N/P ratio of 16:1 (Fig. 2b). The cultures at the N/P ratio of 4:1 experienced a rapid increase and occupied the highest concentration at day 9, while the significant decline happened then, which was in accord with the highest cell density illustrated in Fig. 1b.

For the cultures with an organic nitrogen source (Fig. 2c), the N/P ratio of 100:1 and 50:1 had a remarkable decline after a short rise, which was related to the decrease of the cell abundance. The highest concentration of $\mathrm{Chl} a$ and $\mathrm{PC}$ were 2.1 and $8.1 \mathrm{mg} \mathrm{L}^{-1}$, appeared at N/P ratio of $16: 1$ at day $12(P<0.05)$. The changing trends of the concentration at the N/P ratio of 4:1 was consistent with the results of ammonium medium. 


\section{Photosynthetic activity}

\section{Rapid light curve}

The rapid light curves were measured every three days in each treatment (Fig. 3), together with the corresponding $r E T R_{\max }, E_{k}$ and $\alpha$ values (Tab. 1). For the treatments with $\mathrm{NaNO}_{3}$ medium, the rETR values increased with the increase of nitrogen concentration in the first three days (Fig. 3a). The maximum $r E T R$ value was $29.11(P<0.05)$ obtained at the N/P ratio of 100:1 at day 9, with the corresponding $E_{k}$ and $\alpha$ of $178.84 \mu \mathrm{mol}$ photons $\mathrm{m}^{-2} \mathrm{~s}^{-1}$ and 0.163 , respectively. The group at the N/P ratio of 50:1 presented the maximum $r E T R, E_{k}$ and $\alpha$ values $(18.62,116.52$, $0.160, P<0.05)$ at day 12 compared to the other N/P ratios, which was consistent with the concentration changes of $\mathrm{Chl}$ $a$ and PC showed in Fig. 2a. By contrast, the correlation between the rETR values and nitrogen concentration was negative in the ammonium treatments (Fig. 3b). The cultures with the lowest $\mathrm{N}$ content $(\mathrm{N} / \mathrm{P}$ ratio of $4: 1)$ had the highest $r E T R$ values (26.29 at day 9, with the maximum $E_{k}$ of 169.36, $P<0.05$ ) and the $\alpha$ values were significantly higher than the other treatments at each time point $(0.171$, $0.170,0.155,0.179, P<0.05$ ). However, the most $\mathrm{NH}_{4}$-concentrated cultures (N/P ratios of 100:1 and 50:1) suffered the last two $r E T R$ values, which were not applicable to the curve fitting model of Platt (1980) since day 6, resulting in no data showing for $E_{k}$ and $\alpha$ values (Tab. 1). As for the cultures with the organic nitrogen medium (Fig. 3c), the most beneficial N/P ratio for the algal growth changed during the culture period. Specifically, the cultures with N/P ratios of 100:1 reached the maximum $r E T R$ value at the first two days $(18.74, P<0.05)$. After the first days, the treatments cultured at the N/P ratio of 50:1, 30:1 and 16:1 displayed higher $r E T R$ values $(25.85,28.29$ and 18.44) compared to the other groups successively (day 3, day 6 and day 9 , respectively, $P<0.05$ ). The $r E T R$ values almost fell to 0 in the cultures at an N/P ratio of 4:1 (5.16 at day $12, P<0.05$ ), and no $E_{k}$ value could be calculated from the model, which indicated that the Microcystis cells nearly had no tolerance to the light.
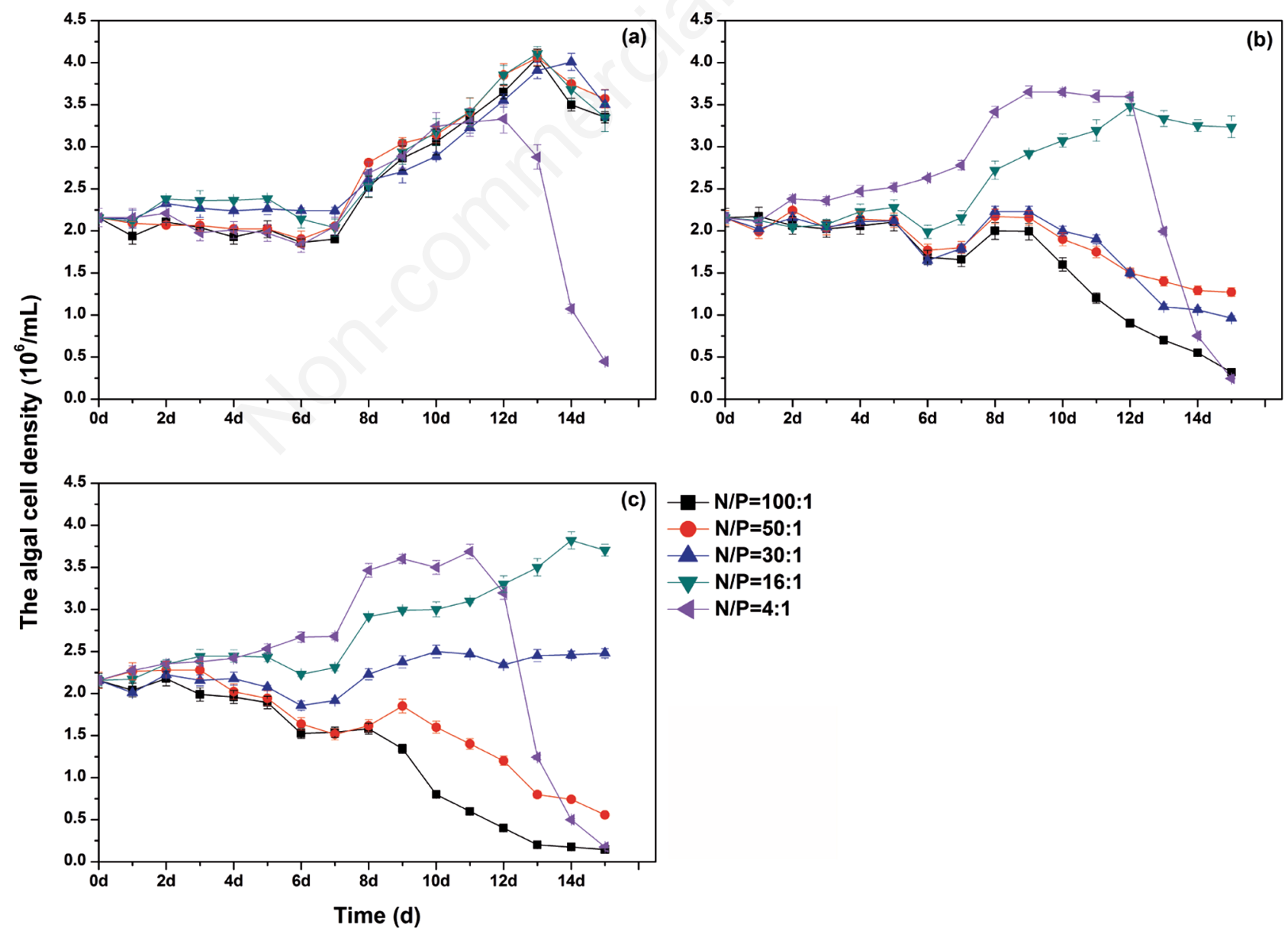

Fig. 1. The cell density of different $\mathrm{N} / \mathrm{P}$ ratios with $\mathrm{NaNO}_{3}(\mathrm{a}), \mathrm{NH}_{4} \mathrm{Cl}$ (b) and $\left[\mathrm{NH}_{2}\right]_{2} \mathrm{CO}$ (c) medium. 


\section{$\varphi P S I I$}

The changes of the actual photochemical efficiency of PSII are listed in Tab. 2. The results of each nitrogen source were significantly different among different $\mathrm{N} / \mathrm{P}$ ratios at each time point $(P<0.05)$. Specifically, the treatments with the nitrate medium at the N/P ratios of 100:1, 50:1 and 30:1 possessed the higher values of $\varphi P S I I$ during the culture period (around 0.3). By contrast, the cultures at the N/P ratio of 16:1 and 4:1 presented low photochemical efficiency gradually, and the lowest $\varphi P S I I$ value was 0.097 (N/P=16:1, $P<0.05)$. By comparison, the values of the ammonium treatments varied a lot among the different N/P ratios. The cultures at the N/P of 4:1 displayed the highest actual photochemical efficiency at each time point $(P<0.05)$, and the maximum value was 0.330 (day $10, P<0.05$ ). The values of the treatments with N/P ratio of $16: 1$ and $30: 1$ had a slight increase from the day 6 while in the more $\mathrm{NH}_{4}$-concentrated treatments (N/P ratio of 100:1 and 50:1) there was a trend towards decline along with time, and the $\varphi P S I I$ values at N/P ratio of 100:1 were significantly lower than other groups during the culture period $(P<0.05)$. In the treatments with urea the $\varphi P S I I$ values were stable for the first 8 days in spite of the N/P ratio of $4: 1$, that decreased and reached the lowest values on day $6(P<0.05)$. The N/P ratio of 30:1 and 16:1 seized the advantage later on, displaying the highest $\varphi P S I I$ values $(P<0.05)$.

$F_{v} / F_{m}$

The maximum photochemical efficiency of the $M$. aeruginosa was detected after 15 min of dark adaptation (Tab. 3). The $F_{v} / F_{m}$ values in the cultures with $\mathrm{NaNO}_{3}$ medium were high (0.4) since the beginning, which indi-

Tab. 1. The values of $\mathrm{rETR}_{\max }, \mathrm{E}_{\mathrm{k}}$ and $\alpha$ with different nitrogen sources at each time point, the results were significant different among different N/P ratios (one-way ANOVA, $P<0.05$ ) Tukey test was used to locate the significant difference.

\begin{tabular}{|c|c|c|c|c|c|c|c|}
\hline & & & 100:1 & $50: 1$ & $30: 1$ & $16: 1$ & $4: 1$ \\
\hline rETRmax & Day 6 & $\begin{array}{l}\mathrm{NaNO}_{3} \\
\mathrm{NH}_{4} \mathrm{Cl} \\
{\left[\mathrm{NH}_{2}\right]_{2} \mathrm{CO}} \\
\mathrm{NaNO}_{3} \\
\mathrm{NH}_{4} \mathrm{Cl} \\
{\left[\mathrm{NH}_{2}\right]_{2} \mathrm{CO}} \\
\mathrm{NaNO}_{3} \\
\mathrm{NH}_{4} \mathrm{Cl} \\
{\left[\mathrm{NH}_{2}\right]_{2} \mathrm{CO}} \\
\mathrm{NaNO}_{3} \\
\mathrm{NH}_{4} \mathrm{Cl} \\
{\left[\mathrm{NH}_{2}\right]_{2} \mathrm{CO}}\end{array}$ & $\begin{array}{c}23.34 \mathrm{a} \\
5.43 \mathrm{e} \\
18.74 \mathrm{a} \\
24.32 \mathrm{a} \\
4.23 \mathrm{~d} \\
14.90 \mathrm{~d} \\
29.11 \mathrm{a} \\
4.12 \mathrm{~d} \\
15.25 \mathrm{c} \\
14.61 \mathrm{c} \\
4.62 \mathrm{e} \\
9.51 \mathrm{~d}\end{array}$ & $\begin{array}{c}20.86 \mathrm{~b} \\
11.14 \mathrm{bc} \\
16.78 \mathrm{c} \\
23.33 \mathrm{~b} \\
3.55 \mathrm{e} \\
25.85 \mathrm{a} \\
21.4 \mathrm{c} \\
4.45 \mathrm{~d} \\
14.64 \mathrm{~d} \\
18.62 \mathrm{a} \\
5.64 \mathrm{~d} \\
10.18 \mathrm{c}\end{array}$ & $\begin{array}{c}15.27 \mathrm{c} \\
8.11 \mathrm{~d} \\
17.62 \mathrm{~b} \\
22.62 \mathrm{c} \\
9.42 \mathrm{c} \\
21.82 \mathrm{c} \\
23.52 \mathrm{~b} \\
10.63 \mathrm{c} \\
28.29 \mathrm{a} \\
16.95 \mathrm{~b} \\
14.97 \mathrm{c} \\
16.22 \mathrm{~b}\end{array}$ & $\begin{array}{c}11.65 \mathrm{e} \\
11.35 \mathrm{~b} \\
15.59 \mathrm{~d} \\
13.81 \mathrm{e} \\
11.57 \mathrm{~b} \\
22.27 \mathrm{~b} \\
10.47 \mathrm{e} \\
13.77 \mathrm{~b} \\
27.43 \mathrm{~b} \\
3.94 \mathrm{e} \\
21.91 \mathrm{a} \\
18.44 \mathrm{a}\end{array}$ & $\begin{array}{c}13.22 \mathrm{~d} \\
16.79 \mathrm{a} \\
11.39 \mathrm{e} \\
16.84 \mathrm{~d} \\
18.99 \mathrm{a} \\
5.29 \mathrm{e} \\
13.41 \mathrm{~d} \\
26.29 \mathrm{a} \\
5.18 \mathrm{e} \\
5.86 \mathrm{~d} \\
19.10 \mathrm{~b} \\
5.16 \mathrm{e}\end{array}$ \\
\hline Ek & Day 9 & $\begin{array}{l}\mathrm{NaNO}_{3} \\
\mathrm{NH}_{4} \mathrm{Cl} \\
{\left[\mathrm{NH}_{2}\right]_{2} \mathrm{CO}} \\
\mathrm{NaNO}_{3} \\
\mathrm{NH}_{4} \mathrm{Cl} \\
{\left[\mathrm{NH}_{2}\right]_{2} \mathrm{CO}} \\
\mathrm{NaNO}_{3} \\
\mathrm{NH}_{4} \mathrm{Cl} \\
{\left[\mathrm{NH}_{2}\right]_{2} \mathrm{CO}} \\
\mathrm{NaNO}_{3} \\
\mathrm{NH}_{4} \mathrm{Cl} \\
{\left[\mathrm{NH}_{2}\right]_{2} \mathrm{CO}}\end{array}$ & $\begin{array}{c}141.41 \mathrm{a} \\
75.43 \mathrm{e} \\
100.99 \mathrm{a} \\
133.87 \mathrm{~b} \\
- \\
90.99 \mathrm{~d} \\
178.84 \mathrm{a} \\
- \\
79.60 \mathrm{~d} \\
107.81 \mathrm{c} \\
- \\
69.93 \mathrm{~d}\end{array}$ & $\begin{array}{c}134.43 \mathrm{~b} \\
100.23 \mathrm{ab} \\
100.19 \mathrm{~b} \\
137.34 \mathrm{a} \\
- \\
135.33 \mathrm{a} \\
148.72 \mathrm{c} \\
- \\
83.05 \mathrm{c} \\
116.52 \mathrm{a} \\
- \\
82.02 \mathrm{c}\end{array}$ & $\begin{array}{c}120.25 \mathrm{c} \\
97.32 \mathrm{~d} \\
90.52 \mathrm{c} \\
124.67 \mathrm{c} \\
99.59 \mathrm{c} \\
130.52 \mathrm{~b} \\
162.10 \mathrm{~b} \\
100.99 \mathrm{c} \\
164.53 \mathrm{a} \\
113.12 \mathrm{~b} \\
103.80 \mathrm{c} \\
157.04 \mathrm{a}\end{array}$ & $\begin{array}{c}93.51 \mathrm{e} \\
100.98 \mathrm{a} \\
86.13 \mathrm{~d} \\
84.78 \mathrm{e} \\
117.56 \mathrm{a} \\
116.91 \mathrm{c} \\
72.86 \mathrm{e} \\
131.43 \mathrm{~b} \\
132.71 \mathrm{~b} \\
63.83 \mathrm{e} \\
166.78 \mathrm{a} \\
140.52 \mathrm{~b}\end{array}$ & $\begin{array}{c}103.92 \mathrm{~d} \\
98.07 \mathrm{c} \\
69.94 \mathrm{e} \\
103.24 \mathrm{~d} \\
111.57 \mathrm{~b} \\
65.17 \mathrm{e} \\
92.28 \mathrm{~d} \\
169.36 \mathrm{a} \\
- \\
73.46 \mathrm{~d} \\
106.92 \mathrm{~b} \\
-\end{array}$ \\
\hline$\alpha$ & Day 12 & $\begin{array}{l}\mathrm{NaNO}_{3} \\
\mathrm{NH}_{4} \mathrm{Cl} \\
{\left[\mathrm{NH}_{2}\right]_{2} \mathrm{CO}} \\
\mathrm{NaNO}_{3} \\
\mathrm{NH}_{4} \mathrm{Cl} \\
{\left[\mathrm{NH}_{2}\right]_{2} \mathrm{CO}} \\
\mathrm{NaNO}_{3} \\
\mathrm{NH}_{4} \mathrm{Cl} \\
{\left[\mathrm{NH}_{2}\right]_{2} \mathrm{CO}} \\
\mathrm{NaNO}_{3} \\
\mathrm{NH}_{4} \mathrm{Cl} \\
{\left[\mathrm{NH}_{2}\right]_{2} \mathrm{CO}}\end{array}$ & $\begin{array}{c}0.165 \mathrm{a} \\
0.072 \mathrm{~d} \\
0.186 \mathrm{~b} \\
0.182 \mathrm{a} \\
- \\
0.164 \mathrm{e} \\
0.163 \mathrm{a} \\
- \\
0.192 \mathrm{~b} \\
0.136 \mathrm{c} \\
- \\
0.136 \mathrm{a}\end{array}$ & $\begin{array}{c}0.155 \mathrm{~b} \\
0.111 \mathrm{bc} \\
0.167 \mathrm{~d} \\
0.170 \mathrm{c} \\
- \\
0.191 \mathrm{a} \\
0.144 \mathrm{~b} \\
- \\
0.176 \mathrm{c} \\
0.160 \mathrm{a} \\
- \\
0.124 \mathrm{c}\end{array}$ & $\begin{array}{c}0.127 \mathrm{c} \\
0.083 \mathrm{bcd} \\
0.195 \mathrm{a} \\
0.181 \mathrm{ab} \\
0.095 \mathrm{c} \\
0.167 \mathrm{~d} \\
0.145 \mathrm{~b} \\
0.105 \mathrm{~b} \\
0.172 \mathrm{~d} \\
0.150 \mathrm{~b} \\
0.144 \mathrm{~b} \\
0.103 \mathrm{~d}\end{array}$ & $\begin{array}{c}0.125 \mathrm{c} \\
0.112 \mathrm{~b} \\
0.181 \mathrm{c} \\
0.163 \mathrm{~d} \\
0.098 \mathrm{~b} \\
0.190 \mathrm{ab} \\
0.144 \mathrm{~b} \\
0.105 \mathrm{~b} \\
0.207 \mathrm{a} \\
0.062 \mathrm{e} \\
0.131 \mathrm{c} \\
0.131 \mathrm{~b}\end{array}$ & $\begin{array}{c}0.127 \mathrm{c} \\
0.171 \mathrm{a} \\
0.163 \mathrm{e} \\
0.163 \mathrm{~d} \\
0.170 \mathrm{a} \\
0.081 \mathrm{c} \\
0.145 \mathrm{~b} \\
0.155 \mathrm{a} \\
- \\
0.080 \mathrm{~d} \\
0.179 \mathrm{a} \\
-\end{array}$ \\
\hline
\end{tabular}

a-c, indicate observations that are statistically indistinguishable. 

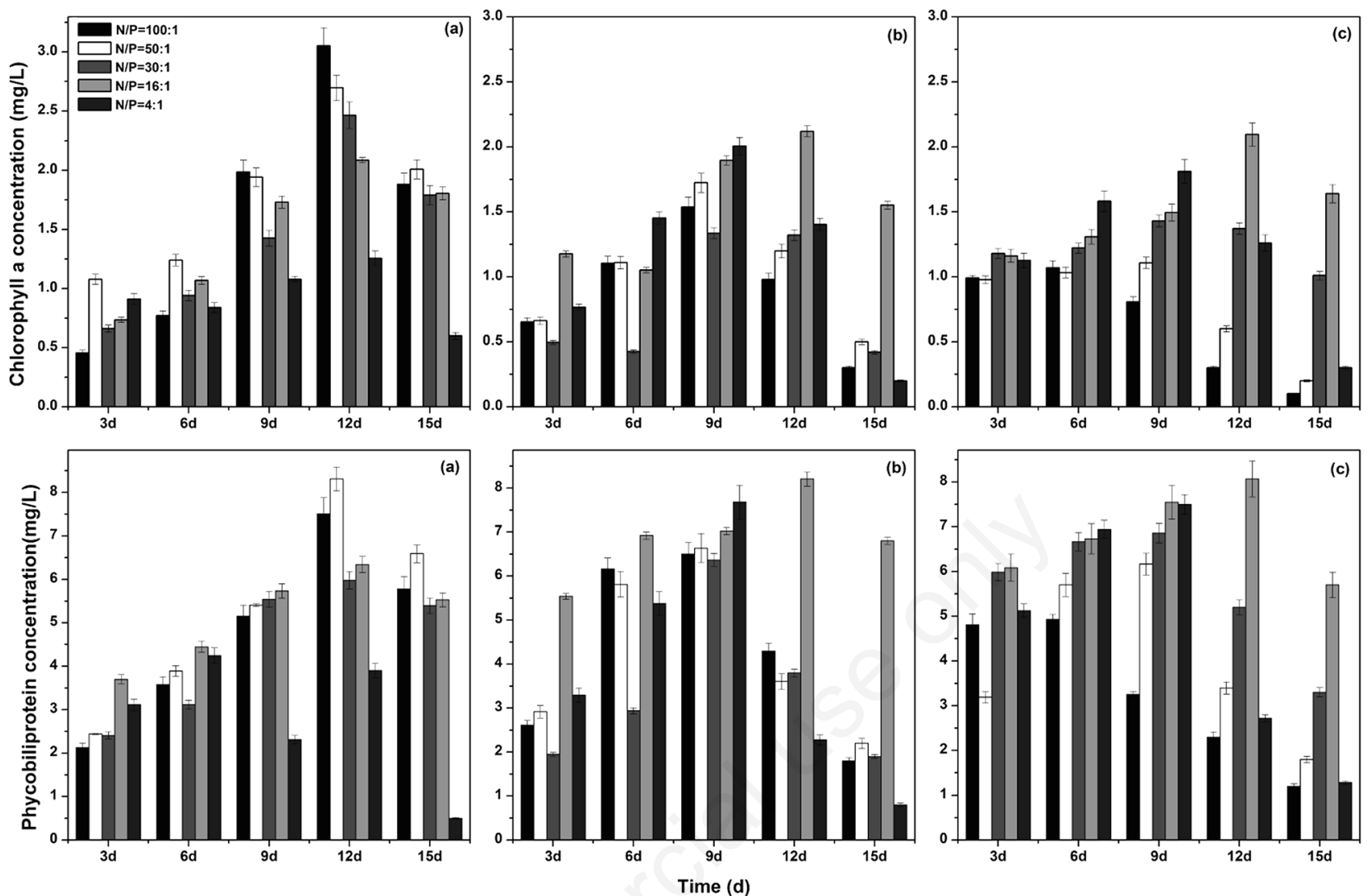

Fig. 2. The chlorophyll-a and phycocyanin concentration of different N/P ratios with $\mathrm{NaNO}_{3}(\mathrm{a}), \mathrm{NH}_{4} \mathrm{Cl}(\mathrm{b})$ and $[\mathrm{NH}]_{2} \mathrm{CO}(\mathrm{c})$ medium.

Tab. 2. The actual photochemical efficiency of PSII ( $\varphi$ PSII) of the cultures with different nitrogen sources at different N/P ratios. Oneway ANOVA was conducted at each N/P ratio at each time point. Tukey's post-hoc test was used to locate the significant difference $(P<0.05)$.

\begin{tabular}{|c|c|c|c|c|c|c|c|}
\hline фPSII & & & 100:1 & $50: 1$ & $30: 1$ & $16: 1$ & $4: 1$ \\
\hline & \multirow{6}{*}{$\mathrm{NaNO}_{3}$} & $2 \mathrm{~d}$ & $0.349 \pm 0.017 \mathrm{ab}$ & $0.336 \pm 0.012 \mathrm{abc}$ & $0.359 \pm 0.010 \mathrm{a}$ & $0.261 \pm 0.011 \mathrm{e}$ & $0.317 \pm 0.016 \mathrm{bcd}$ \\
\hline & & $4 d$ & $0.329 \pm 0.016 \mathrm{a}$ & $0.256 \pm 0.009 \mathrm{~cd}$ & $0.298 \pm 0.009 \mathrm{ab}$ & $0.261 \pm 0.010 \mathrm{~cd}$ & $0.281 \pm 0.014 \mathrm{bc}$ \\
\hline & & $6 d$ & $0.298 \pm 0.015 \mathrm{a}$ & $0.281 \pm 0.010 \mathrm{abc}$ & $0.282 \pm 0.008 \mathrm{ab}$ & $0.233 \pm 0.013 \mathrm{~d}$ & $0.261 \pm 0.012 \mathrm{bcd}$ \\
\hline & & $8 \mathrm{~d}$ & $0.310 \pm 0.016 \mathrm{a}$ & $0.287 \pm 0.010 \mathrm{ab}$ & $0.278 \pm 0.008 \mathrm{bc}$ & $0.211 \pm 0.002 \mathrm{~d}$ & $0.236 \pm 0.012 \mathrm{~d}$ \\
\hline & & $10 \mathrm{~d}$ & $0.291 \pm 0.015 \mathrm{ab}$ & $0.309 \pm 0.011 \mathrm{a}$ & $0.287 \pm 0.008 \mathrm{abc}$ & $0.181 \pm 0.007 \mathrm{e}$ & $0.229 \pm 0.011 \mathrm{~d}$ \\
\hline & & $12 \mathrm{~d}$ & $0.281 \pm 0.014 \mathrm{~b}$ & $0.308 \pm 0.011 \mathrm{a}$ & $0.272 \pm 0.008 \mathrm{bc}$ & $0.097 \pm 0.004 \mathrm{e}$ & $0.132 \pm 0.007 \mathrm{~d}$ \\
\hline & \multirow{6}{*}{$\mathrm{NH}_{4} \mathrm{Cl}$} & $2 d$ & $0.106 \pm 0.0053 \mathrm{e}$ & $0.179 \pm 0.009 \mathrm{~cd}$ & $0.185 \pm 0.009 \mathrm{bc}$ & $0.209 \pm 0.010 \mathrm{~b}$ & $0.315 \pm 0.158 \mathrm{a}$ \\
\hline & & $4 d$ & $0.080 \pm 0.004 \mathrm{e}$ & $0.148 \pm 0.007 \mathrm{bcd}$ & $0.158 \pm 0.010 \mathrm{bc}$ & $0.163 \pm 0.008 \mathrm{~b}$ & $0.280 \pm 0.014 \mathrm{a}$ \\
\hline & & $6 \mathrm{~d}$ & $0.030 \pm 0.002 \mathrm{e}$ & $0.116 \pm 0.006 \mathrm{~cd}$ & $0.141 \pm 0.001 \mathrm{c}$ & $0.171 \pm 0.019 \mathrm{~b}$ & $0.293 \pm 0.011 \mathrm{a}$ \\
\hline & & $8 \mathrm{~d}$ & $0.020 \pm 0.003 \mathrm{e}$ & $0.095 \pm 0.005 \mathrm{~d}$ & $0.137 \pm 0.007 \mathrm{c}$ & $0.196 \pm 0.010 \mathrm{~b}$ & $0.323 \pm 0.010 \mathrm{a}$ \\
\hline & & $10 \mathrm{~d}$ & $0.017 \pm 0.001 \mathrm{e}$ & $0.089 \pm 0.001 \mathrm{~d}$ & $0.210 \pm 0.011 b c$ & $0.233 \pm 0.012 \mathrm{~b}$ & $0.330 \pm 0.013 \mathrm{a}$ \\
\hline & & $12 d$ & $0.013 \pm 0.001 \mathrm{e}$ & $0.068 \pm 0.003 \mathrm{~d}$ & $0.172 \pm 0.009 \mathrm{bc}$ & $0.180 \pm 0.009 \mathrm{~b}$ & $0.260 \pm 0.003 \mathrm{a}$ \\
\hline & \multirow[t]{6}{*}[\mathrm{NH}_{2}]{$_{2} \mathrm{CO}$} & $2 d$ & $0.359 \pm 0.018 \mathrm{a}$ & $0.328 \pm 0.015 \mathrm{abc}$ & $0.347 \pm 0.011 \mathrm{ab}$ & $0.327 \pm 0.012 \mathrm{abcd}$ & $0.306 \pm 0.015 \mathrm{~cd}$ \\
\hline & & $4 d$ & $0.342 \pm 0.017 \mathrm{a}$ & $0.302 \pm 0.014 \mathrm{bc}$ & $0.310 \pm 0.010 \mathrm{ab}$ & $0.265 \pm 0.010 \mathrm{~d}$ & $0.270 \pm 0.014 \mathrm{~cd}$ \\
\hline & & $6 \mathrm{~d}$ & $0.319 \pm 0.016 \mathrm{ab}$ & $0.341 \pm 0.016 \mathrm{a}$ & $0.314 \pm 0.010 \mathrm{abc}$ & $0.279 \pm 0.001 \mathrm{~cd}$ & $0.240 \pm 0.012 \mathrm{e}$ \\
\hline & & $8 \mathrm{~d}$ & $0.306 \pm 0.015 \mathrm{bcd}$ & $0.352 \pm 0.017 \mathrm{a}$ & $0.339 \pm 0.011 \mathrm{ab}$ & $0.336 \pm 0.012 \mathrm{abc}$ & $0.201 \pm 0.010 \mathrm{e}$ \\
\hline & & $10 \mathrm{~d}$ & $0.274 \pm 0.014 \mathrm{c}$ & $0.270 \pm 0.013 \mathrm{~cd}$ & $0.351 \pm 0.012 \mathrm{a}$ & $0.311 \pm 0.012 \mathrm{~b}$ & $0.189 \pm 0.009 \mathrm{e}$ \\
\hline & & $12 d$ & $0.236 \pm 0.012 \mathrm{c}$ & $0.220 \pm 0.010 \mathrm{~cd}$ & $0.338 \pm 0.011 \mathrm{a}$ & $0.321 \pm 0.012 \mathrm{ab}$ & $0.080 \pm 0.004 \mathrm{e}$ \\
\hline
\end{tabular}

$a-c$, indicate observations that are statistically indistinguishable. 

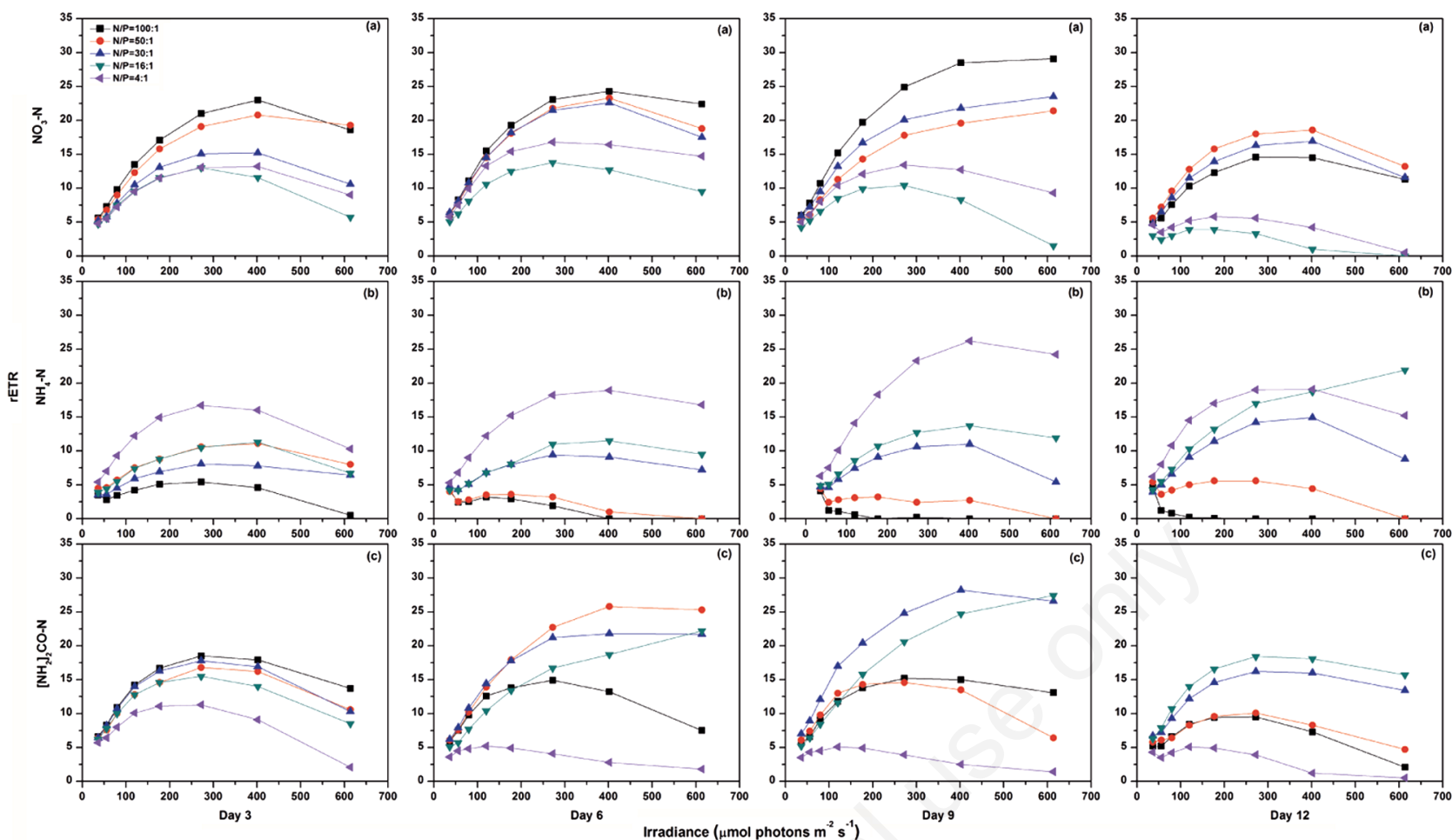

Fig. 3. The rapid light curve (RLC) of different $\mathrm{N} / \mathrm{P}$ ratios with $\mathrm{NaNO}_{3}$ (a), $\mathrm{NH}_{4} \mathrm{Cl}$ (b) and $\left[\mathrm{NH}_{2}\right]_{2} \mathrm{CO}$ (c) medium at day 3, day 6, day 9 and day 12 .

Tab. 3. The maximun photochemical efficiency of PSII $\left(F_{v} / F_{m}\right)$ of the cultures with different nitrogen sources at different N/P ratios. One-way ANOVA was conducted at each N/P ratio at each time point. Tukey's range test was used to locate the significant difference $(P<0.05)$.

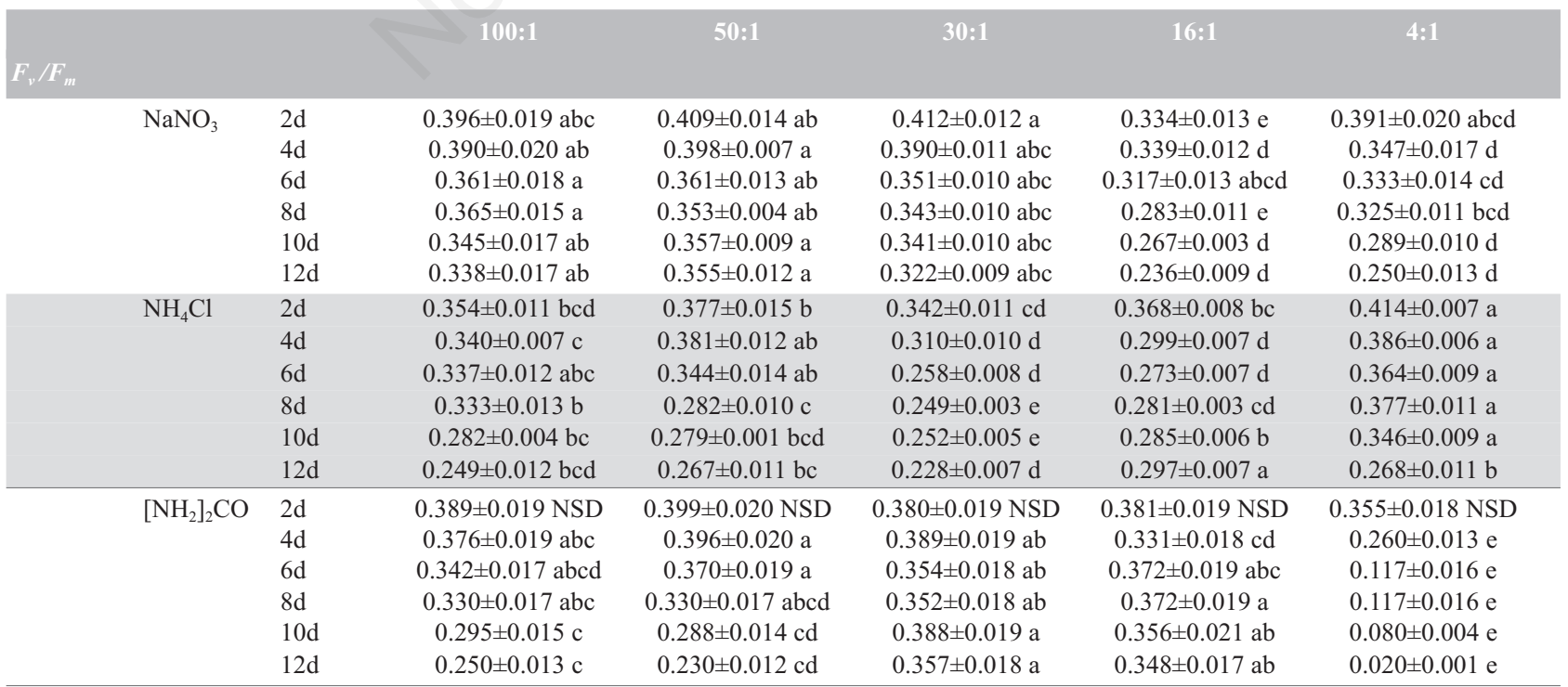

$a-c$, indicate observations that are statistically indistinguishable; NSD, no significant difference. 
cated that $M$. aeruginosa was in good conditions. The treatments richer in nitrate (N/P ratios of 100:1, 50:1 and $30: 1$ ) had the highest values of $F_{v} / F_{m}$, with no significant difference among treatments The maximum $F_{v} / F_{m}$ value of the treatments with $\mathrm{NH}_{4} \mathrm{Cl}$ medium was obtained at the N/P ratio of 4:1 except the day $12(P<0.05)$. The treatments at the N/P ratio of 100:1 and 50:1 had the higher $F_{v} / F_{m}$ values than the other two groups (N/P ratios of 30:1 and 16:1) during all the experiments, opposite to the results of $\varphi P S I I$. Nevertheless, there was no significant difference of $F_{v} / F_{m}$ among all the N/P ratios with urea medium at day 2. A rapid decline appeared in the cultures at the N/P ratio of 4:1 since day 4 , which had the lowest values from then on $(P<0.05)$, while the values remained high at the N/P ratio of 30:1 and 16:1 and were significantly higher from day $10(P<0.05)$.

\section{DISCUSSION}

In many parts of the world, aquatic nitrate concentration range from the background level of below $1.0 \mathrm{mg}$ $\mathrm{L}^{-1}$ to over $100 \mathrm{mg} \mathrm{L}^{-1}$ (Rabalais, 2002; Boyer et al., 2006); while the $\mathrm{NH}_{4}{ }^{+}$concentration may depend upon the urban wastewater treatment process (Leavitt et al., 2006). Moreover, studies have suggested urea may provide 10$50 \%$ of the bioavailable $\mathrm{N}$ in lakes and river surface waters (Wiegner et al., 2006; Bogard et al., 2012). Preliminary evidences suggest that the effects of nitrogen on algal production and composition may be related to the source and chemical composition of the $\mathrm{N}$ added to the lakes (Berman and Chava, 1999; Finlay et al., 2010). In this last studies, significant differences of the Microcystis accumulation, pigment contents and photosynthetic responses were found when they were inoculated to different nitrogen medium at varied N/P ratios, which might shed some light on this topic.

In particular, $M$. aeruginosa were adapted to all N/P levels well and kept high cell abundance even at the high nitrate concentration $\left(\mathrm{NO}_{3} / \mathrm{P}\right.$ ratio of 100:1), which was in accordance with the findings from Nalewajko and Murphy (2001). For the cultures with ammonium medium, the optimal $\mathrm{NH}_{4} / \mathrm{P}$ ratio for the cell growth was between 416 , and the sharp decline at the N/P ratio of 4:1 from the day 12 might be explained by the exhaustion of the nutrient after the exponential growth. Although the maximum cell abundance was obtained at the nitrate treatment, the ammonium cultures achieved the peak first $\left(0.11 \mathrm{~d}^{-1}\right)$, which demonstrated that Microcystis had the priority to use the ammonium. In the presence of $\mathrm{NH}_{4}-\mathrm{N}$, the growth rate of Microcystis should be 4.6 times higher than for $\mathrm{NO}_{3}-\mathrm{N}$ (Sirenko, 1972).

The reason may be that the nitrate needs to be converted to ammonium catalyzed by nitrate reductase (NR) and nitrite reductase $(\mathrm{NiR})$ in the cytosol and chloroplast, respectively, before being incorporated into organic com- pounds (Matthes et al., 1996). However, the toxicity of ammonium is well established in plant and animal systems (Von Wiren and Merrick, 2004). Dai et al. (2012) also reported that the $M$. aeruginosa bloom always happened at the low concentration of ammonia in summer, and disappeared with the decrease of ammonia, which may be attributed to the toxic effect of ammonia to $M$. aeruginosa in spring. Therefore, we infer that the reason for the low cell abundance of the $\mathrm{NH}_{4}$-concentrated cultures (N/P ratios of 100:1, 50:1 and 30:1) in our study may be the ammonium toxicity (Fig. 1b). Furthermore, the energetic advantage of urea may be at least as great as that of $\mathrm{NH}_{4}^{+}$(Berman and Chava, 1999) because urea could be hydrolysed into $\mathrm{NH}_{4}^{+}$and inorganic carbon (C) by urease, encoded by ure $A B C$ genes (Solomon et al., 2010) or by UALase, a single and fused protein encoded by the DUR1,2 gene (Haynes and Mokolobate, 2001). In our study, the Microcystis growth curves of urea cultures were similar to those of $\mathrm{NH}_{4}-\mathrm{N}$ treatments, and N/P ratio favoring algal growth was between 4-30.

Chlorophyll $a$ is a critical photosynthetic pigment also for Microcystis, and its concentration is related to the growth of the algae itself (Ding et al., 2013), while phycocyanin is one of the major phycobiliprotein in phycobilisomes, which plays an important role in funneling light energy to the underlying PSII reaction centers and would especially decrease under conditions of nutrient depletion (Collier and Grossman, 1994; Prasad and Dubey, 2011). The changes in Chl $a$ and PC concentration arose mainly from the variation in Microcystis abundance. The treatments at an N/P ratio of 4:1 had the lowest pigment concentration, since the nitrogen concentration is even low $\left(\mathrm{m}_{\mathrm{N}}=4 \mathrm{mg} / \mathrm{L}\right)$ compared to the background level of lakes and rivers $\left(m_{N}=10 \mathrm{mg} / \mathrm{L}\right)$. The optimal N/P ratio for the ammonium and urea treatments to synthesize pigment were both $16: 1$ in this study, which is in accordance with Redfield's Law (Redfield et al., 1986), and this could be explained by the similar growth curves obtained in our experiment.

Furthermore, the differences of the $\mathrm{N}$ forms and concentration resulted in the variable photosynthetic activity. The $\varphi P S I I$ and $F_{v} / F_{m}$ values declined significantly if the microalgae were under stress. The rapid decrease of $F_{m}$ ' or the increasing proportion of closed PSII reaction centers would lead to the decline of $\varphi P S I I$ according to the formula $\left(\varphi P S I I=\left(\mathrm{F}_{\mathrm{m}}{ }^{\prime}-\mathrm{F}_{\mathrm{s}}\right) / \mathrm{F}_{\mathrm{m}}{ }^{\prime}\right)$ (Wang et al., 2010). It appeared that the $\varphi P S I I$ values were lower in the treatments where $r E T R$ values were low, independently from N/P ratio, which provided more evidence for the nutrient limitation theory of algal growth and photosynthesis. Specifically, Chen et al. (2009) reported that the accumulation of intracellular nitrate could be the cause of inhibition of Microcystis growth and photosynthesis under high nitrate concentration (over $245.1 \mathrm{mg} / \mathrm{L}$ ). In this study, the con- 
centration of $\mathrm{NO}_{3}-\mathrm{N}$ was $422.9 \mathrm{mg} \mathrm{L}{ }^{-1}$ at $\mathrm{N} / \mathrm{P}$ of $100: 1$. As a result, the $r E T R, \varphi P S I I$ and $F_{v} / F_{m}$ values declined, while at N/P ratio of 50:1 they maintained high values from day 12 , suggesting the occurrence of photodamage. Nitrate can regulate NR activity which increases with the increasing of nitrate concentration (Sivasankar and Oaks, 1996), and when nitrite formed by NR is more than the nitrite reduced by NiR, the accumulation of intracellular nitrite will occur, which lead to the inhibition of algal growth and photosynthesis.

As for the ammonium treatments, Zhang et al. (2006) indicated that the photosynthetic activity of the microalgae was high when the concentration of the ammonium was between 1.83 and $18.3 \mathrm{mg} \mathrm{L}^{-1}$. Hence, at the N/P ratio of 4:1 in this study, the concentration of $\mathrm{NH}_{4}-\mathrm{N}$ was $5.14 \mathrm{mg} \mathrm{L}^{-1}$, with the the maximum values of $r E T R$, $\varphi P S I I$ and $F_{v} / F_{m}$ observed, which was conformed to the previous reports. Physiological and genetic research suggested that $\mathrm{N}$ assimilation by cyanobacteria is under centralized control in which low cellular quotas of $\mathrm{NH}_{4}{ }^{+}$ induce genetic mechanisms (activation of NtcA transcription promoter) that increase the active uptake of dissolved or atmospheric N (Herrero et al., 2004; Flores and Herrero, 2005), thereby we speculated that the low concentration of ammonium is more beneficial for the algal photosynthesis.

Few research has been reported about the effect of organic nitrogen medium on the algal photosynthesis. The maximum photosynthetic electron transport rate changed with the N/P ratios in the urea treatments, the more concentrated treatments had the higher $r E T R$ values at the beginning. Moreover, the $\varphi P S I I$ and $F_{v} / F_{m}$ values were pretty low at the N/P ratio of $4: 1$, which might be due to the decrease of the efficiency of electron transport from the primary quinone-type acceptor ( $\mathrm{QA}^{-}$) to $\mathrm{QB}$ (Antal et al., 2009; Petrou et al., 2012), or to the decline of the $\mathrm{D}_{1}$ protein concentration, which is low under nutrient deficient conditions (Steglich et al., 2001). Huang et al. (2014) also reported that low urea concentrations did not sustainably promote the growth, photosynthesis and toxin production of the M. aeruginosa. The urease is present in live microbial cells, which determines the hydrolysis rate of urea (Fisher et al., 2016). However, during this process, $\mathrm{CO}_{2}$ is released by intracellular urease (Flores and Herrero, 2005), which might change the $\mathrm{pH}$ of the solutions (Haynes and Mokolobate, 2001), having a significant impact on the urease activity, as well as on the $\mathrm{CO}_{2}$ fixation rate of photosynthesis (Klemer et al., 1982).

\section{CONCLUSIONS}

Overall, our observations provide insight into the effects of nitrogen forms (inorganic and organic) and varied N/P ratios on the biomass and photosynthetic activity of M. aeruginosa FACHB-905. Significant differences of Mi- crocystis numbers, pigment contents and photosynthetic responses revealed that: i) $M$. aeruginosa can adapt to medium-high nitrate concentrations $(\mathrm{N} / \mathrm{P}=30-50)$, while too-high concentrations $(\mathrm{N} / \mathrm{P}=100: 1)$ would cause an intracellular nitrate inhibition, which induce a decrease of the photosynthetic activity; ii) low concentration of $\mathrm{NH}_{4}^{-}$ $\mathrm{N}(\mathrm{N} / \mathrm{P}=4)$ would favor the $M$. aeruginosa growth and photosynthesis, with the maxmium $r E T R, E_{k}, \alpha, \varphi P S I I$, $F_{v} / F_{m}$ values of $26.29,169.36,0.179,0.330$ and 0.414 , respectively, while too high $\mathrm{NH}_{4} / \mathrm{P}$ ratio $(>16)$ would rise the ammonium toxicity of algal cells and affect the $\mathrm{N}$ assimilation; iii) the organic nitrogen (urea) is a bioavailable form of $\mathrm{N}$ and in our experiments the highest growth of $M$. aeruginosa was observed at N/P ratio between 16-30; while the values of the photosynthetic parameters $(r E T R$, $\varphi P S I I$ and $F_{v} / F_{m}$ ) were pretty low (almost 0 ) at the N/P ratio of $4: 1$. Thus, we speculate that the nitrogen chemical forms and the N/P ratios are two important factors for cyanobacterial growth and photosynthetic activity. The control of nitrogen inputs during the algal blooms should not be ignored. However, further studies like the antioxidant system activity assay and the molecular response should be carried out to clarify the mechanisms of the photosynthetic response to nutrient stress.

\section{ACKNOWLEDGMENTS}

This study was supported jointly by the Project of Investigation and Evaluation of Ecological Security in Cuijiaying Reservoir, Xiangyang (WDH1829002), the Major Project Foundation of China National Social Science (14ZDB140), the Project of Ecological environmental Protection and Planning of Taiping Lake (Huangshan District)(SAH1829116), the Grant Project of National Climate Change Center and international clean production: Research on the Climate Change and Adaptive Index System of Cities.

\section{REFERENCES}

Aneesh CN, Haridas A, Manilal VB, 2015. Role of nutrients input pattern on the growth dynamics of common freshwater microalgal community. Am. J. Plant Sci. 6:2481.

Antal T, Matorin D, Ilyash L, Volgusheva A, Osipov V, Konyuhov I, Krendeleva T, Rubin A, 2009. Probing of photosynthetic reactions in four phytoplanktonic algae with a PEA fluorometer. Photosynth. Rese. 102:67-76.

Barbiero RP, James WF, Barko JW, 1999. The effects of disturbance events on phytoplankton community structure in a small temperate reservoir. Freshwater Biol. 42:503-512.

Belisle BS, Steffen MM, Pound HL, Watson SB, Debruyn JM, Bourbonniere RA, Boyer GL, Wilhelm SW (2016). Urea in Lake Erie: organic nutrient sources as potentially important drivers of phytoplankton biomass. J. Great Lakes Res. (In press).

Berman T, Chava S, 1999. Algal growth on organic compounds as nitrogen sources. J. Plankton Res. 21:1423-1437. 
Bogard MJ, Donald DB, Finlay K, Leavitt PR, 2012. Distribution and regulation of urea in lakes of central North America. Freshwater Biol. 57:1277-1292.

Boyer EW, Howarth RW, Galloway JN, Dentener FJ, Green PA, Vörösmarty CJ, 2006. Riverine nitrogen export from the continents to the coasts. Global Biogeochem. Cycles 20: GB1S91.

Bulgakov N, Levich A, 1999. The nitrogen: phosphorus ratio as a factor regulating phytoplankton community structure: nutrient ratios. Arch. Hydrobiol. 146:3-22.

Chen W, Zhang Q, Dai S, 2009. Effects of nitrate on intracellular nitrite and growth of Microcystis aeruginosa. J. Appl. Phycol. 21:701-706.

Collier JL, Grossman A, 1994. A small polypeptide triggers complete degradation of light-harvesting phycobiliproteins in nutrient-deprived cyanobacteria. EMBO J. 13:1039.

Dai GZ, Shang JL, Qiu BS, 2012. Ammonia may play an important role in the succession of cyanobacterial blooms and the distribution of common algal species in shallow freshwater lakes. Global Change Biol. 18:1571-1581.

Ding LP, Ma YY, Huang BX, Chen SW, 2013. Effects of seawater salinity and temperature on growth and pigment contents in Hypnea cervicornis J. Agardh (Gigartinales, Rhodophyta). BioMed Res. Int. 2013:594308.

Dolman AM, Rücker J, Pick FR, Fastner J, Rohrlack T, Mischke U, Wiedner C, 2012. Cyanobacteria and cyanotoxins: the influence of nitrogen versus phosphorus. PloS One 7:e38757.

Donald DB, Bogard MJ, Finlay K, Leavitt PR, 2011. Comparative effects of urea, ammonium, and nitrate on phytoplankton abundance, community composition, and toxicity in hypereutrophic freshwaters. Limnol. Oceanogr. 56:21612175.

Finlay K, Patoine A, Donald DB, Bogard MJ, Leavitt PR, 2010. Experimental evidence that pollution with urea can degrade water quality in phosphorus-rich lakes of the Northern Great Plains. Limnol. Oceanogr. 55:1213-1230.

Fisher KA, Meisinger JJ, James BR, 2016. Urea hydrolysis rate in soil toposequences as influenced by $\mathrm{pH}$, carbon, nitrogen, and soluble metals. J. Environ. Qual. 45:349-359.

Flores E, Herrero A, 2005. Nitrogen assimilation and nitrogen control in cyanobacteria. Biochem. Soc. T. 33:164-167.

Geider RJ, Maclntyre HL, Kana TM, 1998. A dynamic regulatory model of phytoplanktonic acclimation to light, nutrients, and temperature. Limnol. Oceanogr. 43:679-694.

Genty B, Briantais J-M, Baker NR, 1989. The relationship between the quantum yield of photosynthetic electron transport and quenching of chlorophyll fluorescence. BBA-Gen. Subjects 990:87-92.

Harke MJ, Gobler CJ, 2013. Global transcriptional responses of the toxic cyanobacterium, Microcystis aeruginosa, to nitrogen stress, phosphorus stress, and growth on organic matter. PLoS One 8:e69834.

Haynes R, Mokolobate M, 2001. Amelioration of Al toxicity and P deficiency in acid soils by additions of organic residues: a critical review of the phenomenon and the mechanisms involved. Nutr. Cycl. Agroecosyst. 59:47-63.

Herrero A, Muro-Pastor AM, Valladares A, Flores E, 2004. Cellular differentiation and the NtcA transcription factor in filamentous cyanobacteria. FEMS Microbiol. Rev. 28:469-487.

Huang W, Bi Y, Hu Z, 2014. Effects of fertilizer-urea on growth, photosynthetic activity and microcystins production of Microcystis aeruginosa isolated from Dianchi lake. B. Environ. Contam. Tox. 92:514-519.

Hyenstrand P, Blomqvist P, Pettersson A, 1998. Factors determining cyanobacterial success in aquatic systems: a literature review, p. 41-62. In: C. Forsberg and K. Pettersson (eds.), Lake Erken - 50 years of limnological research. Advances in Limnology. 51. Schweizerbart, Stuttgart.

Juneau P, Green B, Harrison P, 2005. Simulation of Pulse-Amplitude-Modulated (PAM) fluorescence: limitations of some PAM-parameters in studying environmental stress effects. Photosynthetica 43:75-83.

Klemer A, Feuillade J, Feuillade M, 1982. Cyanobacterial blooms: carbon and nitrogen limitation have opposite effects on the buoyancy of oscillatoria. Science 215:1629-1631.

Leavitt PR, Brock CS, Ebel C, Patoine A, 2006. Landscape-scale effects of urban nitrogen on a chain of freshwater lakes in central North America. Limnol. Oceanogr. 51:2262-2277.

Lehman EM, Mcdonald KE, Lehman JT, 2009. Whole lake selective withdrawal experiment to control harmful cyanobacteria in an urban impoundment. Water Res. 43:1187-1198.

Lehman P, Kendall C, Guerin M, Young M, Silva S, Boyer G, Teh S, 2015. Characterization of the Microcystis bloom and its nitrogen supply in San Francisco Estuary using stable isotopes. Estuaries Coasts 38:165-178.

Lippemeier S, Hintze R, Vanselow K, Hartig P, Colijn F, 2001. In-line recording of PAM fluorescence of phytoplankton cultures as a new tool for studying effects of fluctuating nutrient supply on photosynthesis. Eur. J. Phycol. 36:89-100.

Liu Y, Chen X, Zhang J, Gao B, 2015. Hormesis Effects of amoxicillin on growth and cellular biosynthesis of Microcystis aeruginosa at different nitrogen levels. Microb. Eco. 69:608-617.

Matthes HW, Maldonado R, Simonin F, Valverde O, Slowe S, Kitchen I, Befort K, Dierich A, Le Meur M, Dollé P, 1996. Loss of morphine-induced analgesia, reward effect and withdrawal symptoms in mice lacking the mu-opioid-receptor gene. Nature 383:819-823.

McCarthy MJ, James RT, Chen Y, East TL, Gardner WS, 2009. Nutrient ratios and phytoplankton community structure in the large, shallow, eutrophic, subtropical Lakes Okeechobee (Florida, USA) and Taihu (China). Limnology 10:215-227.

Moisander PH, Ochiai M, Lincoff A, 2009. Nutrient limitation of Microcystis aeruginosa in northern California Klamath River reservoirs. Harmful Algae 8:889-897.

Nalewajko C, Murphy TP, 2001. Effects of temperature, and availability of nitrogen and phosphorus on the abundance of Anabaena and Microcystis in Lake Biwa, Japan: an experimental approach. Limnology 2:45-48.

Padgett MP, Krogmann DW, 1987. Large scale preparation of pure phycobiliproteins. Photosynth. Res. 11:225-235.

Parsons TR, Maita Y, Lalli CM, 1984. A manual of biological and chemical methods for seawater analysis. Pergamon Press, Oxford: $173 \mathrm{pp}$.

Peng G, Fan Z, Wang X, Sui X, Chen C, 2015. Photodegradation of microcystin-LR catalyzed by metal phthalocyanines immobilized on $\mathrm{TiO}_{2}-\mathrm{SiO}_{2}$ under visible-light irradiation. Water Sci. Technol. 72:1824-1831.

Petrou K, Kranz SA, Doblin MA, Ralph PJ, 2012. Photophysiological responses of fragilariopsis cylindrus (bacillario- 
phyceae) to nitrogen depletion at two temperatures. J. Phycol. 48:127-136.

Platt T, Gallegos C, Harrison W, 1980. Photoinhibition of photosynthesis in natural assemblages of marine phytoplankton in the Arctic. Deep-Sea Res. 29:1159-1170.

Prasad SM, Dubey G, 2011. Growth, pigments and photosynthetic responses of two cyanobacteria adapted to varying light intensities. Plant Arch. 11:621-629.

Rabalais NN, 2002. Nitrogen in aquatic ecosystems. Ambio 31:102-112.

Ralph PJ, Gademann R, 2005. Rapid light curves: a powerful tool to assess photosynthetic activity. Aquat. Bot. 82:222-237.

Redfield A, Ketchum B, Richards F, 1986. On phytoplankton growth rates and particulate C:N: P ratios at low light. Mar. Biol 16:49-58.

Rippka R, Deruelles J, Waterbury JB, Herdman M, Stanier RY, 1979. Generic assignments, strain histories and properties of pure cultures of cyanobacteria. Microbiology 111:1-61.

Schindler D, 1977. Evolution of phosphorus limitation in lakes. Science 195:260-262.

Schindler DW, Hecky R, Findlay D, Stainton M, Parker B, Paterson M, Beaty K, Lyng M, Kasian S, 2008. Eutrophication of lakes cannot be controlled by reducing nitrogen input: results of a 37-year whole-ecosystem experiment. P. Natl. Acad. Sci. USA 105:11254-11258.

Schreiber U, Bilger W, Hormann H, Neubauer C, 2000. Chlorophyll fluorescence as a diagnostic tool: basics and some aspects of practical relevance, p. 320-336. In: A.S. Raghavendra (ed.), Photosynthesis - A comprehensive treatise. Cambridge University Press.

Schreiber U, Müller JF, Haugg A, Gademann R, 2002. New type of dual-channel PAM chlorophyll fluorometer for highly sensitive water toxicity biotests. Photosynth. Res. 74: 317-330.

Sivasankar S, Oaks A, 1996. Nitrate assimilation in higher plants: the effect of metabolites and light. Plant Physiol. Biochem. 34:609-620.

Sirenko LA, 1972. [Physiological principals of the growth of blue-green algae in reservoirs.].[Book in Russian]. Naukova Dumka, Kiev: 203 pp.

Smith VH, 1983. Low nitrogen to phosphorus ratios favor dominance by blue-green algae in lake phytoplankton. Science 221:669-671.

Solomon CM, Collier JL, Berg GM, Glibert PM, 2010. Role of urea in microbial metabolism in aquatic systems: a biochemical and molecular review. Aquat. Microb. Ecol. 59:67-88.

Steffen MM, Dearth SP, Dill BD, Li Z, Larsen KM, Campagna SR, Wilhelm SW, 2014. Nutrients drive transcriptional changes that maintain metabolic homeostasis but alter genome architecture in Microcystis. ISME J. 8:2080-2092.

Steglich C, Behrenfeld M, Koblizek M, Claustre H, Penno S, Prasil O, Partensky F, Hess WR, 2001. Nitrogen deprivation strongly affects photosystem II but not phycoerythrin level in the divinyl-chlorophyll b-containing cyanobacterium Prochlorococcus marinus. BBA-Bioenergetics 1503:341-349.

Ting CS, Owens TG, 1992. Limitations of the pulse-modulated technique for measuring the fluorescence characteristics of algae. Plant Physiol. 100:367-373.

Von Wiren N, Merrick M, 2004. Regulation and function of ammonium carriers in plants, yeast and bacteria. Trends Curr. Genet. 9:95-120.

Wang Z, Li D, Li G, Liu Y, 2010. Mechanism of photosynthetic response in Microcystis aeruginosa PCC7806 to low inorganic phosphorus. Harmful Algae 9:613-619.

White S, Anandraj A, Bux F, 2011. PAM fluorometry as a tool to assess microalgal nutrient stress and monitor cellular neutral lipids. Bioresource Technol. 102:1675-1682.

White S, Duivenvoorden L, Fabbro L, 2005. Impacts of a toxic Microcystis bloom on the macroinvertebrate fauna of Lake Elphinstone, Central Queensland, Australia. Hydrobiologia 548:117-126.

Wiegner TN, Seitzinger SP, Glibert PM, Bronk DA, 2006. Bioavailability of dissolved organic nitrogen and carbon from nine rivers in the eastern United States. Aquat. Microb. Ecol. 43:277-287.

Wilhelm SW, Lecleir GR, Bullerjahn GS, Mckay RM, Saxton MA, Twiss MR, Bourbonniere RA, 2014. Seasonal changes in microbial community structure and activity imply winter production is linked to summer hypoxia in a large lake. FEMS Microbiol. Ecol. 87:475-485.

Yan Y, Dai R, Liu Y, Gao J, Wu X, 2015. Comparative effects of inorganic and organic nitrogen on the growth and microcystin production of Microcystis aeruginosa. World J. Microbiol. Biotechnol. 31:763-772.

Zhang W, Lin YQ, Guo DF, Fu JJ, Zhao YJ, 2006. Influence of different nitrogen and phosphorus concentations on growth, photosysthesis and microcystin production of Microcystis aeruginosa. Acta Hydrobiol. Sin. 30:318-322. 